Rev. Bras. Saúde Prod. Anim., Salvador, v.17, n.4, p.626-641 out./dez., 2016 http://www.rbspa.ufba.br ISSN 15199940

\title{
Ensiling a dry bakery by-product: effect of hydration using acid whey or water associated or not at urea
}

\author{
Ensilagem de resíduo seco de padaria: efeito da hidratação utilizando soro ácido de \\ leite ou água associada ou não à ureia
}
REZENDE, Adauton Vilela de ${ }^{1}$; RABELO, Carlos Henrique Silveira ${ }^{2}$; SAMPAIO, Lucas de Moura ${ }^{1}$; HÄRTER, Carla Joice ${ }^{2}$; FLORENTINO, Ligiane Aparecida ${ }^{1}$; PAULA, Deyvid Wilker ${ }^{1}$; BRAGA, Tatiane Cristina ${ }^{1}$

\author{
${ }^{1}$ Universidade José do Rosário Velllano, Instituto de Ciências Agrárias, Departamento de Agronomia, \\ Alfenas, Minas Gerais, Brasil. \\ ${ }^{2}$ Universidade Estadual Paulista, Faculdade de Ciências Agrárias e Veterinárias, Departamento de \\ Zootecnia, Jaboticabal, São Paulo, Brasil. \\ *Endereço para correspondência: carlos.zoo@hotmail.com
}

\section{SUMMARY}

The objective of this study was to investigate the characteristics of silages prepared with a dry bakery by-product hydrated with acid whey or water associated or not at urea. The trial was a 3 (hydration at three moisture levels: 250, 300, and $350 \mathrm{~mL} \mathrm{~kg}^{-1}$ of by-product) $\times 3$ (three application rates of urea: 0,5 , and $10 \mathrm{~g} \mathrm{~kg}^{-1}$ of by-product) $\times 2$ (liquid used at hydration: acid whey or water) factorial arrangement. Minisilos were used as experimental silos and remained closed for 30 days. Overall, silages hydrated with acid whey had higher $(\mathrm{P}<0.01)$ production of lactic (19.6 vs. $18.5 \mathrm{~g} \mathrm{~kg}^{-1}$ of dry matter $[\mathrm{DM}])$, acetic (2.5 vs. $1.8 \mathrm{~g} \mathrm{~kg}^{-1}$ of DM) and propionic acid ( 8.0 vs. $5.4 \mathrm{~g} \mathrm{~kg}^{-1}$ of DM), and lower $(\mathrm{P}<0.05)$ fungi counts $(5.35$ and 5.01 cfu $\mathrm{g}^{-1}$ of fresh silage) compared to silages hydrated with water. Increased hydration led to the higher production of total acids $(\mathrm{P}<0.01)$, decreasing silage $\mathrm{pH}$; but increased hydration reduced DM recovery $(\mathrm{P}<0.01)$. Silages hydrated with water and acid whey at $250 \mathrm{~mL}$ $\mathrm{kg}^{-1}$ and combined at 5 and $10 \mathrm{~g} \mathrm{~kg}^{-1}$ of urea exhibited higher DM recovery $(\mathrm{P}<0.05)$. Silages of a dry bakery by-product hydrated with acid whey had a better fermentation pattern and could represent a practical strategy to avoid discarding both by-products into environment.

Keywords: alternative feed, chemical composition, fungi, lactic acid bacteria

\section{RESUMO}

O objetivo com este estudo foi investigar as características de silagens preparadas com um resíduo seco de padaria hidratado com soro ácido de leite ou água associado ou não à ureia. O experimento foi conduzido em um arranjo fatorial 3 (três níveis de hidratação: 250, 300 e 350 mL kg${ }^{1}$ de subproduto) $\times 3$ (três níveis de aplicação de ureia: 0,5 e $10 \mathrm{~g} \mathrm{~kg}^{-1}$ de subproduto) $\times 2$ (dois líquidos usados na hidratação: soro ácido de leite ou água). Mini silos foram utilizados como silos experimentais e permaneceram fechados por 30 dias. Em geral, silagens hidratadas com soro ácido de leite apresentaram maior $(\mathrm{P}<0,01)$ produção de ácido lático (19,6 vs. $18,5 \mathrm{~g} \mathrm{~kg}^{-1}$ de matéria seca [MS]), ácido acético (2,5 vs. $1,8 \mathrm{~g} \mathrm{~kg}^{-1}$ de MS) e ácido propiônico ( 8,0 vs. $5,4 \mathrm{~g} \mathrm{~kg}^{-1}$ de MS), e menores $(\mathrm{P}<0,05)$ contagens de fungos $(5,35 \mathrm{e}$ 5,01 ufg $\mathrm{g}^{-1}$ de silagem fresca) comparadas às silagens hidratadas com água. A maior hidratação das silagens aumentou a produção total de ácidos $(\mathrm{P}<0,01)$ reduzindo os valores de $\mathrm{pH}$; mas o aumento na hidratação reduziu $(\mathrm{P}<0,01)$ a recuperação de MS das silagens. Silagens hidratadas com água e soro ácido de leite a 250 $\mathrm{mL} \mathrm{kg}{ }^{-1}$ e combinado com 5 e $10 \mathrm{~g} \mathrm{~kg}^{-1}$ de ureia exibiram maior $(\mathrm{P}<0,05)$ recuperação de $\mathrm{MS}$. Silagens de resíduo seco de padaria hidratadas com soro ácido de leite apresentaram melhor padrão fermentativo, podendo representar uma estratégia prática para evitar o descarte de ambos os subprodutos no ambiente.

Palavras-chave: alimento alternativo, bactérias ácido-láticas, composição química, fungos 


\section{INTRODUCTION}

Brazil produced over 2 millions of tonnes of bakery products in 2015 (ABIMAPI, 2015 ), and approximately $7.5 \%$ to $10.0 \%$ was wasted or lost during the process of production (GARCIA et al., 2011). Thus, considerable amounts of bakery byproducts are available and could be used to animal feeding reducing costs (KWAK \& KANG, 2006; FRANÇA et al., 2012). However, bakery products are not stable per se once this food has a considerable population of Penicillium and Aspergillus spp. which are able to growth in warmer climates and can cause serious problems of spoilage (SUHR \& NIELSEN, 2004). Moreover, storing bakery by-products in humid and hot places (e.g., barns on the farm) could lead the growth of fungi and the production of mycotoxins impairing animal production. Thus, ensiling process is likely an adequate alternative to allow the use of bakery by-products in animal feeding as reported for other by-products (MAKKAR \& ANKERS, 2014).

Bakery by-products often have low moisture and fermentable sugar (MORAES et al., 2010; ELLEUCH et al., 2011), and the total amount of acids produced must be quite low and similar to high-moisture corn (HMC) silages (KUNG et al., 2007). Therefore, hydration of bakery by-products could be a good strategy to allow their ensiling and obtain a desirable fermentation pattern as observed for rehydrated cereal grains, apart from improvements on feed efficiency (RICHARDS \& HICKS, 2007; PIEPER et al., 2011). Normally, the liquid used at hydration or rehydration process is water, but acid whey displayed a good potential to improve the fermentation of rehydrated HMC silages (REZENDE et al., 2014). Moreover, this strategy would avoid serious environmental problems because acid whey is rich in various nutrients and cannot be discarded in watercourses or lakes.

In contrast, some microorganisms can convert soluble carbohydrates into undesirable products during fermentation and increase dry matter (DM) losses, as well as yeasts are able to growth in aerobic conditions utilizing products of the fermentation and impair the nutritive value of silage (PAHLOW et al., 2003). In this regard, the antifungal properties of urea may reduce the activity of undesirable microorganisms and fermentative losses of silages (PEDROSO et al., 2008; 2011), besides to increase crude protein content.

The objective of this study was to investigate the characteristics of silages prepared with a dry bakery by-product hydrated with acid whey or water associated or not at urea.

\section{MATERIAL AND METHODS}

The dry bakery by-product was composed of different types and proportions of cracker, biscuits and cookies and was obtained from the food industry. The byproduct exhibited a moisture content of $110 \mathrm{~g} \mathrm{~kg}^{-1}$ as fed (Table 1). A stationary chopper was used to reduce the size of the bakery by-product to a length of $10 \mathrm{~mm}$. Then, buckets (capacity of $30 \mathrm{~L}$ ) were used to allow the hydration of bakery byproduct with clean water or acid whey, which was obtained from a cheese manufacturer (Table 2). This process was performed under constant mixing to ensure a good homogenization. Water and acid whey were applied at 250, 300, and $350 \mathrm{~mL} \mathrm{~kg}{ }^{-1}$ of bakery by-product to obtain a similar DM content observed in some high-moisture corn silages used on farms (REZENDE et al., 2014). 
Rev. Bras. Saúde Prod. Anim., Salvador, v.17, n.4, p.626-641 out./dez., 2016 http://www.rbspa.ufba.br

Table 1. Chemical composition of the dry bakery by-product (overall mean and standard error of the mean)

\begin{tabular}{lc}
\hline Item $^{1}$ & Bakery by-product \\
\hline $\mathrm{DM}, \mathrm{g} \mathrm{kg}^{-1}$ as fed & $889.8 \pm 1.95$ \\
$\mathrm{OM}$ & $982.1 \pm 0.68$ \\
$\mathrm{Ash}$ & $17.9 \pm 0.68$ \\
$\mathrm{CP}$ & $104.4 \pm 3.96$ \\
$\mathrm{EE}$ & $87.1 \pm 4.61$ \\
$\mathrm{pH}$ & $5.86 \pm 0.06$ \\
$\mathrm{LAB}, \log _{10} \mathrm{cfu} \mathrm{g}^{-1}$ & $5.62 \pm 0.04$ \\
Fungi, $\log _{10} \mathrm{cfu} \mathrm{g}^{-1}$ & $6.15 \pm 0.31$ \\
\hline
\end{tabular}

${ }^{\mathrm{T}} \mathrm{DM}=$ dry matter; $\mathrm{OM}=$ organic matter; $\mathrm{CP}=$ crude protein; $\mathrm{EE}=$ ether extract; $\mathrm{LAB}=$ lactic acid bacteria.

Table 2. Characteristics of the acid whey used at hydration of a dry bakery by-product

\begin{tabular}{lcc}
\hline Item $^{1}$ & Whole-acid whey & Dried acid whey \\
\hline Density, $\mathrm{g} \mathrm{L}^{-1}$ at $15^{\circ} \mathrm{C}$ & 1036.1 & $\mathrm{NA}$ \\
Acidity, ${ }^{\circ} \mathrm{D}$ & 14.5 & - \\
Cryoscopy, ${ }^{\circ} \mathrm{H}$ & -0.641 & $\mathrm{NA}$ \\
Temperature, ${ }^{\circ} \mathrm{C}$ & 39.0 & - \\
$\mathrm{pH}$ & 5.4 & - \\
$\mathrm{DM}, \mathrm{g} \mathrm{kg}^{-1}$ as fed & 51.4 & 51.2 \\
$\mathrm{CP}, \mathrm{g} \mathrm{kg}^{-1}$ & 4.1 & 13.3 \\
$\mathrm{Lipid}, \mathrm{g} \mathrm{kg}^{-1}$ & 1.3 & 107.2 \\
\hline Ash, $\mathrm{g} \mathrm{kg}^{-1}$ & 9.6 & \\
\hline
\end{tabular}

${ }^{1} \mathrm{DM}=$ dry matter; $\mathrm{CP}=$ crude protein, $\mathrm{NA}=$ not applicable.

Additionally, for each hydration level we evaluated the application of three rates of urea $\left(0,5\right.$, and $10 \mathrm{~g} \mathrm{~kg}^{-1}$ of bakery by-product). This process was performed under constant mixing to ensure a good homogenization on already hydrated bakery by-product. The urea used in this study exhibited $281.25 \mathrm{~g}$ of non-protein nitrogen - NPN (equivalent in crude protein - CP) per kilogram, besides $500 \mathrm{mg} \mathrm{kg}^{-1}$ of fumaric acid, $10 \mathrm{~g} \mathrm{~kg}^{-1}$ of $\mathrm{S}, 40 \mathrm{~g} \mathrm{~kg}^{-1}$ of $\mathrm{P}, 100 \mathrm{~g} \mathrm{~kg}^{-1}$ of $\mathrm{Ca}, 117 \mathrm{~g} \mathrm{~kg}^{-1}$ of $\mathrm{Na}$, $0.6 \mathrm{mg} \mathrm{kg}^{-1}$ of $\mathrm{Mn}, 13 \mathrm{mg} \mathrm{kg}^{-1}$ of $\mathrm{Se}$, $120 \mathrm{mg} \mathrm{kg}^{-1}$ of I, $140 \mathrm{mg} \mathrm{kg}^{-1}$ of $\mathrm{Co}$, $450 \mathrm{mg} \mathrm{kg}^{-1}$ of $\mathrm{F}, 1,400 \mathrm{mg} \mathrm{kg}^{-1}$ of $\mathrm{Cu}$ and $2,500 \mathrm{mg} \mathrm{kg}^{-1}$ of $\mathrm{Zn}$. The chemical composition of bakery by-product prior to ensiling is showed in Table 3.
Mini-silos (PVC tubes with a capacity of $4 \mathrm{~L}$ ) were used as experimental silos, and stored in a room (at ambient temperature) remaining closed for $30 \mathrm{~d}$. Each mini-silo contained $0.5 \mathrm{~kg}$ of sand in the bottom separated by a fine screen to avoid the contact between silage and sand, besides a gas release valve. Then, the silos were opened, and DM recovery was calculated as follows:

$\mathrm{DM}$ recovery $\left(\mathrm{g} \mathrm{kg}^{-1}\right)=\left(\mathrm{F}_{\mathrm{op}} * \mathrm{DM}_{\mathrm{op}}\right) /$ $\left(\mathrm{F}_{\mathrm{en}} * \mathrm{DM}_{\mathrm{en}}\right) * 100(1)$

where $\mathrm{F}_{\mathrm{op}}$ and $\mathrm{DM}_{\mathrm{op}}=$ by-product mass and DM content at the silo opening, respectively; and $\mathrm{F}_{\mathrm{en}}$ and $\mathrm{DM}_{\mathrm{en}}=$ byproduct mass and DM content at ensiling, respectively. 
Rev. Bras. Saúde Prod. Anim., Salvador, v.17, n.4, p.626-641 out./dez., 2016 http://www.rbspa.ufba.br ISSN 15199940

Table 3. Chemical composition $\left(\mathrm{g} \mathrm{kg}^{-1}\right.$ of DM) and microbiology profile $\left(\log _{10} \mathrm{cfu}^{-1}\right.$ of fresh matter) of bakery by-product hydrated with water or acid whey and treated or not with urea prior to ensiling $(n=3)$

\begin{tabular}{lcccccccc}
\hline Item $^{1}$ & $\mathrm{DM}^{\mathrm{g} \mathrm{g} \mathrm{g}^{-1}}$ as fed & $\mathrm{OM}$ & $\mathrm{Ash}$ & $\mathrm{CP}$ & $\mathrm{EE}$ & $\mathrm{pH}$ & $\mathrm{LAB}$ & Fungi \\
\hline Liquid & & & & & & & & \\
\hline Water & 689.3 & 977.3 & 22.4 & 121.4 & 89.5 & 5.95 & 5.81 & 6.03 \\
Whey & 692.5 & 975.3 & 24.7 & 125.4 & 96.7 & 5.90 & 6.64 & 7.31 \\
\hline Hydration, $\mathrm{mL} \mathrm{kg}^{-1}$ & & & & & & & & \\
\hline 250 & 735.2 & 978.1 & 21.9 & 112.3 & 81.4 & 6.09 & 6.18 & 6.57 \\
300 & 707.7 & 976.3 & 23.2 & 124.6 & 89.7 & 5.94 & 6.22 & 6.49 \\
350 & 629.8 & 974.6 & 25.4 & 133.3 & 108.3 & 5.75 & 6.27 & 6.96 \\
\hline Urea, $\mathrm{g} \mathrm{kg}^{-1}$ & & & & & & & & \\
\hline 0 & 688.6 & 980.8 & 19.2 & 106.7 & 91.3 & 5.85 & 5.97 & 6.93 \\
5 & 689.9 & 975.3 & 24.7 & 122.8 & 93.0 & 5.86 & 6.13 & 6.72 \\
10 & 694.2 & 972.9 & 26.6 & 140.7 & 95.0 & 6.06 & 6.58 & 6.37 \\
\hline
\end{tabular}

${ }^{\mathrm{T}} \mathrm{DM}=$ dry matter; $\mathrm{OM}=$ organic matter; $\mathrm{CP}=$ crude protein; $\mathrm{EE}=$ ether extract; $\mathrm{LAB}=$ lactic acid bacteria.

For fermentative analyses of silage samples, $25 \mathrm{~g}$ of fresh silage was mixed with $225 \mathrm{~mL}$ of distilled water. This mixture was blended in a blender (Commercial blender, model Philips, Walita, Varginha, Minas Gerais, Brazil) for $30 \mathrm{~s}$ at the highest speed and filtered through 2 layers of cheesecloth. The $\mathrm{pH}$ of the filtrate was measured immediately with a $\mathrm{pH}$ meter (MA522 model, Marconi Laboratory Equipment, Piracicaba, São Paulo, Brazil). The levels of lactic, acetic, propionic, butyric, oxalic, and phytic acids were measured by high-performance liquid chromatography

([HPLC]; CARVALHO et al., 2012). The acids were identified by comparing their retention times with those of known standards. The concentrations of the identified compounds were determined by the external calibration method. The HPLC apparatus (model LC-10Ai, Shimadzu Corp., Tokyo, Japan) was equipped with a dual detection system consisting of a UV detector (UV-Vis SPD-10Ai) and a refractive index detector (RID 10A). An ion exclusion column from Shimadzu (Shim-pack SCR-101H; $7.9 \mathrm{~mm}$ i.d., $30 \mathrm{~cm}$ long) operated at $50^{\circ} \mathrm{C}$ was used for the chromatographic separation. The mobile phase consisted of $100 \mathrm{~m} M$ perchloric acid solution with a flow rate of $0.6 \mathrm{~mL}$ $\min ^{-1}$. The acids were detected by UV absorbance $(210 \mathrm{~nm})$.

Other silage samples were oven dried $\left(55^{\circ} \mathrm{C}\right.$ for $\left.72 \mathrm{~h}\right)$, processed in a knife mill before passing through a $1-\mathrm{mm}$ screen, and analyzed for $\mathrm{DM}\left(105^{\circ} \mathrm{C}\right.$ for $12 \mathrm{~h})$ and ash $\left(500^{\circ} \mathrm{C}\right.$ for $\left.5 \mathrm{~h}\right)$. The DM content of bakery by-product silages was corrected for the volatile losses that occur during oven drying using the equation proposed by Porter \& Murray (2001).

True DM content $\left(\mathrm{g} \mathrm{kg}^{-1}\right)=1.011 \times$

$\mathrm{ODM}+1.24$

where ODM = oven dry matter.

The organic matter (OM) was calculated as 1000 minus ash. The total $\mathrm{N}$ (TN) was determined using the Kjeldahl method (AOAC, 1996; method no. 954.01), and the crude protein (CP) was calculated as $\mathrm{TN} \times 6.25$. The ether extract (EE) was measured according to the procedures of AOAC (1996, method no. 920.39).

For the microbiological analyses, a fresh silage sample of $25 \mathrm{~g}$ from each replicate was homogenized in $225 \mathrm{~mL}$ of saline solution $(\mathrm{NaCl} 0.85 \%)$ for 1 
min. Then, we transferred $1 \mathrm{~mL}$ of this solution to tubes with $9 \mathrm{~mL}$ of saline solution, and $1 \mathrm{~mL}$ of this mixture was plated onto Petri plates at dilutions of $10^{-1}$ to $10^{-9}$. Rogosa agar was used to count lactic-acid bacteria (LAB), whereas BDA agar was used to count yeasts and molds (fungi), and Violet Red Bile agar was used to count enterobacteria. The BDA agar plates were incubated at $36^{\circ} \mathrm{C}$, whereas the other plates were incubated at $35.5^{\circ} \mathrm{C}$ for $2 \mathrm{~d}$. All of the microbiological data were log-transformed.

The experiment was organized in a completely randomized design with three replicates. The fermentation profile and chemical composition were analyzed with a mixed model using the MIXED procedure of SAS (v 9.4), considering hydration, type of liquid and urea levels as fixed effects and the residual error as a random effect. The following general model was used:

$$
Y_{i j k}=\mu+H_{i}+L_{j}+U_{k}+H L_{i j}+H U_{i k}+L U_{j k}+H L U_{i j k}+e_{i j k}
$$

where $Y_{i j k}=$ response variable; $\mu=$ overall mean; $H=$ effect of hydration level $i ; L=$ effect of liquid $j ; U=$ effect of urea rate $k ; H L=$ effect of interaction between hydration level $i$ and liquid $j$; $H U=$ effect of interaction between hydration level $i$ and urea rate $k ; L U=$ effect of interaction between liquid $j$ and urea rate $k ; H L U=$ effect of interaction among hydration level $i$, liquid $j$ and urea rate $k$; and $e_{i j k}=$ error term.

When necessary, residual variances, distinct to "hydration", "type of liquid" and/or "urea" subclasses were modeled using the GROUP option of the REPEATED statement. Differences between the means were determined using the P-DIFF option of the LSMEANS statement, which differentiates the means based on Fisher's F-protected least significant difference test. Contrasts were constructed, and the single degree-offreedom orthogonal comparisons included the linear and quadratic effects of hydration and urea levels. The differences were declared significant at $\mathrm{P} \leq 0.05$ and trends at $0.05>\mathrm{P} \leq 0.10$. Moreover, regression equations for main effect of hydration level and urea rate and their interactions were constructed through the REG procedure of SAS. When significant interactions included the qualitative effect (i.e., liquid used at hydration), the BY statement of the REG procedure was used. Regression equations were showed only whether significant at $\mathrm{P} \leq 0.05$.

\section{RESULTS}

All data about the chemical composition of bakery by-product silages after ensiling are given in Table 4. The DM, $\mathrm{OM}$, ash and EE were influenced by interaction between all factors evaluated (liquid, hydration level, and urea rate), and $\mathrm{CP}$ was influenced by interaction between liquid and hydration level.

The bakery by-product silages exhibited higher $(\mathrm{P}<0.01) \mathrm{DM}$ content at $250 \mathrm{~mL}$ $\mathrm{kg}^{-1}$ (745.9 $\mathrm{g} \mathrm{kg}^{-1}$ as fed), followed by silages hydrated at 300 and $350 \mathrm{~mL} \mathrm{~kg}^{-1}$ (711.6 and $623.1 \mathrm{~g} \mathrm{~kg}^{-1}$ as fed, respectively). Overall, the DM values were similar within each hydration level, except for those silages untreated with urea and hydrated with water and acid whey at $250 \mathrm{~mL} \mathrm{~kg}^{-1}$, where the acid whey increased the DM content compared to water. 
Table 4. Chemical composition ( $\mathrm{g} \mathrm{kg}^{-1}$ of $\mathrm{DM}$ ) of bakery by-product silages hydrated with water or acid whey and treated or not with urea $(\mathrm{n}=3)$

\begin{tabular}{|c|c|c|c|c|c|c|c|}
\hline Hydration, $\mathrm{mL} \mathrm{kg}^{-1}$ & Liquid & Urea, $\mathrm{g} \mathrm{kg}^{-1}$ & $\mathrm{DM}, \mathrm{g} \mathrm{kg}^{-1}$ as fed & $\mathrm{OM}$ & Ash & $\mathrm{CP}$ & $\mathrm{EE}$ \\
\hline \multirow[t]{6}{*}{250} & Water & 0 & $739.1^{b}$ & $983.8^{\mathrm{a}}$ & $16.2^{\mathrm{f}}$ & $91.6^{\mathrm{f}}$ & $74.4^{\mathrm{f}}$ \\
\hline & & 5 & $742.6^{\mathrm{ab}}$ & $977.6^{\mathrm{d}}$ & $22.4^{\mathrm{c}}$ & $109.4^{\mathrm{f}}$ & $77.1^{\mathrm{f}}$ \\
\hline & & 10 & $741.4^{\mathrm{ab}}$ & $976.4^{\mathrm{d}}$ & $23.6^{\mathrm{c}}$ & $122.0^{\mathrm{f}}$ & $77.7^{\mathrm{f}}$ \\
\hline & Whey & 0 & $756.3^{\mathrm{a}}$ & $981.7^{\mathrm{b}}$ & $18.3^{\mathrm{e}}$ & $96.4^{\mathrm{e}}$ & $82.3^{\mathrm{e}}$ \\
\hline & & 5 & $749.1^{\mathrm{ab}}$ & $977.2^{\mathrm{d}}$ & $22.8^{\mathrm{c}}$ & $110.4^{\mathrm{e}}$ & $80.0^{\mathrm{f}}$ \\
\hline & & 10 & $746.9^{\mathrm{ab}}$ & $973.7^{\mathrm{f}}$ & $26.3^{\mathrm{a}}$ & $125.6^{\mathrm{e}}$ & $84.2^{\mathrm{e}}$ \\
\hline \multirow[t]{6}{*}{300} & Water & 0 & $710.0^{\mathrm{c}}$ & $982.7^{\mathrm{b}}$ & $17.3^{\mathrm{e}}$ & $103.2^{\mathrm{d}}$ & $87.0^{\text {de }}$ \\
\hline & & 5 & $708.5^{\mathrm{c}}$ & $976.6^{\mathrm{d}}$ & $23.4^{\mathrm{c}}$ & $115.1^{\mathrm{d}}$ & $80.4^{\text {ef }}$ \\
\hline & & 10 & $712.0^{\mathrm{c}}$ & $974.8^{\mathrm{e}}$ & $25.2^{\mathrm{b}}$ & $132.4^{\mathrm{d}}$ & $82.8^{\mathrm{e}}$ \\
\hline & Whey & 0 & $699.8^{c}$ & $980.5^{\mathrm{bc}}$ & $19.5^{\mathrm{de}}$ & $109.1^{\mathrm{c}}$ & $91.2^{\mathrm{d}}$ \\
\hline & & 5 & $717.1^{\mathrm{c}}$ & $975.0^{\mathrm{e}}$ & $25.0^{\mathrm{b}}$ & $123.7^{\mathrm{c}}$ & $92.1^{\mathrm{d}}$ \\
\hline & & 10 & $722.3^{\mathrm{c}}$ & $972.0^{\mathrm{f}}$ & $28.0^{\mathrm{a}}$ & $138.3^{\mathrm{c}}$ & $95.1^{\mathrm{cd}}$ \\
\hline \multirow[t]{6}{*}{350} & Water & 0 & $618.4^{\mathrm{d}}$ & $980.9^{\mathrm{bc}}$ & $19.1^{\mathrm{de}}$ & $112.2^{\mathrm{b}}$ & $96.8^{\mathrm{c}}$ \\
\hline & & 5 & $615.5^{\mathrm{d}}$ & $975.4^{\mathrm{e}}$ & $24.6^{\mathrm{b}}$ & $125.8^{\mathrm{b}}$ & $99.7^{\mathrm{c}}$ \\
\hline & & 10 & $626.2^{\mathrm{d}}$ & $972.9^{f}$ & $27.1^{\mathrm{a}}$ & $144.3^{\mathrm{b}}$ & $105.2^{\mathrm{b}}$ \\
\hline & Whey & 0 & $626.3^{\mathrm{d}}$ & $977.9^{\mathrm{d}}$ & $22.1^{\mathrm{c}}$ & $118.5^{\mathrm{a}}$ & $109.9^{\mathrm{b}}$ \\
\hline & & 5 & $621.6^{\mathrm{d}}$ & $972.7^{\mathrm{f}}$ & $27.3^{\mathrm{a}}$ & $131.4^{\mathrm{a}}$ & $114.4^{\mathrm{a}}$ \\
\hline & & 10 & $630.8^{\mathrm{d}}$ & $971.4^{\mathrm{f}}$ & $28.6^{\mathrm{a}}$ & $146.0^{\mathrm{a}}$ & $108.6^{\mathrm{b}}$ \\
\hline SEM & & & 5.67 & 0.34 & 0.34 & 0.99 & 1.58 \\
\hline \multirow[t]{4}{*}{$P$-value ${ }^{1,2}$} & & $\mathrm{H}$ & $<0.0001$ & $<0.0001$ & $<0.0001$ & $<0.0001$ & $<0.0001$ \\
\hline & & $\mathrm{L}$ & $<0.0001$ & $<0.0001$ & $<0.0001$ & $<0.0001$ & $<0.0001$ \\
\hline & & $\mathrm{U}$ & 0.0825 & $<0.0001$ & $<0.0001$ & $<0.0001$ & 0.0848 \\
\hline & & Interaction & $\mathrm{H} \times \mathrm{L} \times \mathrm{U}^{*}$ & $\mathrm{H} \times \mathrm{L} \times \mathrm{U}^{*}$ & H x L x U* & $\mathrm{H} \times \mathrm{L}^{*}$ & $\mathrm{H} \times \mathrm{L} \times \mathrm{U}^{*}$ \\
\hline \multirow[t]{2}{*}{ Main contrast ${ }^{3}$} & & $\mathrm{H}$ & $\mathrm{Q}^{* *}$ & $\mathrm{~L}^{* *}$ & $\mathrm{~L}^{* *}$ & $\mathrm{~L}^{* *}$ & $\mathrm{Q}^{* *}$ \\
\hline & & $\mathrm{U}$ & $\mathrm{Q}^{*}$ & $\mathrm{Q}^{* *}$ & $\mathrm{Q}^{* *}$ & $\mathrm{~L}^{* *}$ & $\mathrm{~L}^{*}$ \\
\hline
\end{tabular}

${ }^{\mathrm{a}-\mathrm{f}}$ Means in the same column with different superscripts differed $(\mathrm{P}<0.05) ;{ }^{1} \mathrm{H}=$ hydration; $\mathrm{L}=$ liquid used at hydration; $\mathrm{U}=$ urea; ${ }^{2} * \mathrm{P}<0.05 ; * * \mathrm{P}<0.01$.

${ }^{3} \mathrm{~L}=$ linear effect; $\mathrm{Q}=$ quadratic effect.

$\mathrm{DM}=$ dry matter; $\mathrm{OM}=$ organic matter; $\mathrm{CP}=$ crude protein; $\mathrm{EE}=$ ether extract 
For ash, the bakery by-product silages treated with $10 \mathrm{~g} \mathrm{~kg}^{-1}$ of urea and hydrated with acid whey at the three moisture levels had higher $(\mathrm{P}<0.05)$ values (overall mean of $27.6 \mathrm{~g} \mathrm{~kg}^{-1}$ of DM) together the silage hydrated with acid whey at $350 \mathrm{~mL} \mathrm{~kg}^{-1}$ and treated with $5 \mathrm{~g} \mathrm{~kg}^{-1}$ of urea.

The CP of bakery by-product silages increased by 10.1 and $18.7 \%$ when hydration was performed at 300 and 350 $\mathrm{mL} \mathrm{\textrm {kg } ^ { - 1 }}$ compared to the silages hydrated at $250 \mathrm{~mL} \mathrm{~kg}^{-1}\left(109.2 \mathrm{~g} \mathrm{~kg}^{-1}\right.$ of $\mathrm{DM} ; \quad \mathrm{P}<0.05)$, and within each hydration level, the acid whey promoted higher values compared to water (increases of 2.9, 5.8 and $3.6 \%$ at 250 , 300 and $350 \mathrm{~mL} \mathrm{~kg}^{-1}$, respectively), considering the overall means.

The EE content increased when the water or acid whey was added, wherein the highest value $(\mathrm{P}<0.05)$ was observed in the silage hydrated with acid whey and treated with $5 \mathrm{~g} \mathrm{~kg}^{-1}$ of urea.

All data about the fermentation and microbiology profile of bakery byproduct silages after ensiling are given in Table 5. The $\mathrm{pH}$, lactic acid, propionic acid, oxalic acid, phytic acid, total acids, and LAB were influenced by interaction between all factors evaluated (liquid, hydration level, and urea rate). The DM recovery was influenced by interaction between hydration level and urea rate; and acetic acid, lactic: acetic acid ratio, and fungi were not affected by any interaction.

Overall, the $\mathrm{pH}$ decreased with high levels of hydration $(\mathrm{P}<0.01)$; however, higher $\mathrm{pH}$ values were observed in the silages hydrated with acid whey at 350 $\mathrm{mL} \mathrm{kg}$ and with $10 \mathrm{~g} \mathrm{~kg}^{-1}$ of urea, besides silage hydrated with water at $250 \mathrm{~mL} \mathrm{~kg}^{-1}$ and with $10 \mathrm{~g} \mathrm{~kg}^{-1}$ of urea. Increases in the hydration level increased lactic acid $(\mathrm{P}<0.01)$, resulting in overall means of $13.8,18.7$, and 24.7 $\mathrm{g} \mathrm{kg}^{-1}$ of DM at 250,300 , and $350 \mathrm{~mL}$ $\mathrm{kg}^{-1}$, respectively; and the higher values were observed for silages hydrated at $350 \mathrm{~mL} \mathrm{~kg}^{-1}$ using water (plus $5 \mathrm{~g} \mathrm{~kg}^{-1}$ of urea) and acid whey (plus $10 \mathrm{~g} \mathrm{~kg}^{-1}$ of urea). However, is important to state that acid whey allowed higher lactic acid production in general $(6.0 \%)$ compared to silages hydrated with water (19.6 vs. $18.5 \mathrm{~g} \mathrm{~kg}^{-1}$ of DM, respectively).

Comparing the liquids used at hydration, the concentration of acetic acid was higher when acid whey was used ( $\mathrm{P}<0.01$; overall means of 2.52 vs. $1.80 \mathrm{~g} \mathrm{~kg}^{-1}$ of DM for water). For hydration levels the overall means were $1.76,2.30$, and $2.41 \mathrm{~g} \mathrm{~kg}^{-1}$ of DM at 250, 300, and $350 \mathrm{~mL} \mathrm{~kg}^{-1}$, respectively; and for urea rates the overall means were 2.28, 2.31, and 1.89 $\mathrm{g} \mathrm{kg}^{-1}$ of DM at 0,5 , and $10 \mathrm{~g} \mathrm{~kg}^{-1}$, respectively. These results indicate increases in acetic acid of $40.0 \%$ when acid whey was used for hydration compared to water, and increases of 30.7 and $36.9 \%$ when hydration was performed at 300 and $350 \mathrm{~mL} \mathrm{~kg}^{-1}$ compared to $250 \mathrm{~mL} \mathrm{~kg}^{-1}$, respectively. Relative to the lactic: acetic acid ratio, silages hydrated with acid whey had higher ratio $(\mathrm{P}<0.01$; overall means of 10.1 vs. 7.7 for water), whereas silages hydrated at 250,300 , and $350 \mathrm{~mL} \mathrm{~kg}^{-1}$ exhibited overall means of $7.8,8.5$, and 10.4, respectively $(\mathrm{P}<0.01)$. The urea rates did not influence the lactic: acetic acid ratio $(\mathrm{P}>0.05)$.

Propionic acid exhibited higher values when water or acid whey was added $(\mathrm{P}<0.01)$, and the highest values were obtained from bakery by-product silages hydrated with acid whey at $350 \mathrm{~mL} \mathrm{~kg}^{-1}$ untreated or with $5 \mathrm{~g} \mathrm{~kg}^{-1}$ of urea. Butyric acid was evaluated but not detectable. 
Table 5. Fermentation $\left(\mathrm{g} \mathrm{kg}^{-1}\right.$ of $\left.\mathrm{DM}\right)$ and microbiology profile $\left(\log _{10} \mathrm{cfu}^{-1}\right.$ of fresh matter) of bakery by-product silages hydrated with water or acid whey and treated or not with urea $(n=3)$

\begin{tabular}{|c|c|c|c|c|c|c|c|c|c|c|c|c|c|}
\hline Hydration, $\mathrm{mL} \mathrm{kg}^{-1}$ & Liquid & ${ }_{1}^{\text {Urea, }} \mathrm{g} \mathrm{kg}^{-}$ & $\mathrm{pH}$ & Lactic acid & Acetic acid & L:A ratio & Propionic acid & Oxalic acid ${ }^{4}$ & Phytic acid ${ }^{4}$ & Total acids & DM recovery & LAB & Fungi \\
\hline \multirow[t]{6}{*}{250} & \multirow[t]{3}{*}{ Water } & 0 & $4.41^{\mathrm{c}}$ & $12.1^{\mathrm{f}}$ & 1.5 & 8.7 & $4.6^{\mathrm{f}}$ & $73.1^{\circ}$ & $22.3^{\mathrm{c}}$ & $18.3^{\mathrm{f}}$ & $951.1^{\mathrm{c}}$ & $5.78^{\mathrm{b}}$ & 5.75 \\
\hline & & 5 & $4.59^{\mathrm{b}}$ & $14.2^{\mathrm{ef}}$ & 1.5 & 9.7 & $5.8^{\mathrm{e}}$ & $78.4^{\mathrm{f}}$ & $19.3^{\mathrm{j}}$ & $21.6^{\mathrm{e}}$ & $980.2^{\mathrm{ab}}$ & $5.58^{\mathrm{c}}$ & 5.14 \\
\hline & & 10 & $5.17^{\mathrm{a}}$ & $13.2^{\mathrm{f}}$ & 1.5 & 6.9 & $1.3^{\mathrm{g}}$ & $73.3^{\mathrm{m}}$ & $21.9^{\mathrm{d}}$ & $15.7^{\mathrm{g}}$ & $982.5^{\mathrm{a}}$ & $5.68^{\mathrm{b}}$ & 4.98 \\
\hline & \multirow[t]{3}{*}{ Whey } & 0 & $4.61^{\mathrm{b}}$ & $13.0^{\mathrm{f}}$ & 2.2 & 6.0 & $5.6^{\mathrm{e}}$ & $83.4^{\mathrm{a}}$ & $14.1^{\mathrm{p}}$ & $20.9^{\mathrm{e}}$ & $968.1^{\mathrm{c}}$ & $5.96^{\mathrm{b}}$ & 5.23 \\
\hline & & 5 & $4.72^{\mathrm{b}}$ & $14.9^{\mathrm{e}}$ & 2.3 & 6.6 & $6.6^{\mathrm{de}}$ & $77.9^{\mathrm{i}}$ & $19.3^{\mathrm{j}}$ & $23.9^{\mathrm{d}}$ & $966.5^{\mathrm{ab}}$ & $6.04^{\mathrm{b}}$ & 4.87 \\
\hline & & 10 & $4.21^{\mathrm{d}}$ & $15.4^{\mathrm{e}}$ & 1.7 & 8.8 & $6.9^{\mathrm{d}}$ & $80.9^{b}$ & $15.7^{\circ}$ & $23.8^{\mathrm{e}}$ & $984.7^{\mathrm{a}}$ & $5.70^{\mathrm{b}}$ & 4.93 \\
\hline \multirow[t]{6}{*}{300} & \multirow[t]{3}{*}{ Water } & 0 & $4.19^{\mathrm{d}}$ & $18.1^{\mathrm{d}}$ & 1.9 & 9.4 & $6.7^{\mathrm{d}}$ & $80.5^{\mathrm{c}}$ & $16.9^{\mathrm{n}}$ & $26.8^{\mathrm{c}}$ & $961.4^{\mathrm{c}}$ & $5.76^{\mathrm{b}}$ & 5.92 \\
\hline & & 5 & $4.35^{\mathrm{bc}}$ & $18.2^{\mathrm{d}}$ & 2.3 & 8.0 & $6.2^{\mathrm{de}}$ & $76.9^{\mathrm{j}}$ & $20.3^{g}$ & $26.8^{\mathrm{c}}$ & $968.6^{\mathrm{c}}$ & $5.94^{\mathrm{b}}$ & 5.30 \\
\hline & & 10 & $4.50^{\mathrm{bc}}$ & $17.2^{\mathrm{d}}$ & 1.7 & 10.7 & $4.0^{\mathrm{f}}$ & $79.4^{\mathrm{e}}$ & $18.5^{1}$ & $22.9^{\mathrm{de}}$ & $965.7^{\mathrm{c}}$ & $5.94^{\mathrm{b}}$ & 4.91 \\
\hline & \multirow[t]{3}{*}{ Whey } & 0 & $4.33^{\mathrm{bc}}$ & $19.4^{\mathrm{cd}}$ & 2.8 & 6.9 & $8.9^{c}$ & $75.1^{1}$ & $20.7^{\mathrm{f}}$ & $31.1^{\mathrm{b}}$ & $949.9^{c}$ & $5.90^{\mathrm{b}}$ & 5.06 \\
\hline & & 5 & $4.45^{\mathrm{bc}}$ & $19.5^{\mathrm{c}}$ & 2.9 & 6.8 & $8.5^{\mathrm{c}}$ & $76.3^{\mathrm{k}}$ & $76.3^{\mathrm{a}}$ & $31.1^{\mathrm{b}}$ & $960.9^{c}$ & $5.92^{\mathrm{b}}$ & 4.77 \\
\hline & & 10 & $4.74^{\mathrm{b}}$ & $19.8^{\mathrm{c}}$ & 2.2 & 9.2 & $7.6^{\mathrm{d}}$ & $77.9^{\mathrm{i}}$ & $19.2^{\mathrm{k}}$ & $29.7^{\mathrm{b}}$ & $950.9^{c}$ & $5.75^{\mathrm{b}}$ & 5.36 \\
\hline \multirow[t]{6}{*}{350} & \multirow[t]{3}{*}{ Water } & 0 & $4.10^{\mathrm{d}}$ & $22.0^{\mathrm{b}}$ & 2.1 & 11.2 & $7.1^{\mathrm{d}}$ & $73.0^{\mathrm{p}}$ & $21.2^{\mathrm{e}}$ & $31.4^{\mathrm{b}}$ & $912.0^{\mathrm{d}}$ & $5.70^{\mathrm{b}}$ & 5.78 \\
\hline & & 5 & $4.02^{\mathrm{d}}$ & $28.0^{\mathrm{a}}$ & 1.8 & 13.2 & $8.0^{\mathrm{c}}$ & $78.2^{\mathrm{h}}$ & $19.7^{\mathrm{i}}$ & $37.8^{\mathrm{a}}$ & $915.1^{\mathrm{d}}$ & $5.48^{\mathrm{c}}$ & 5.24 \\
\hline & & 10 & $4.15^{\mathrm{d}}$ & $23.6^{\mathrm{b}}$ & 1.9 & 12.8 & $4.7^{\mathrm{f}}$ & $73.2^{\mathrm{n}}$ & $22.6^{\mathrm{b}}$ & $31.5^{\mathrm{b}}$ & $931.1^{\mathrm{cd}}$ & $5.81^{\mathrm{b}}$ & 5.10 \\
\hline & \multirow[t]{3}{*}{ Whey } & 0 & $4.08^{\mathrm{d}}$ & $23.0^{\mathrm{b}}$ & 3.1 & 7.4 & $10.5^{\mathrm{a}}$ & $75.1^{1}$ & $20.7^{\mathrm{f}}$ & $36.8^{\mathrm{a}}$ & $900.4^{\mathrm{d}}$ & $5.83^{\mathrm{b}}$ & 4.93 \\
\hline & & 5 & $4.11^{\mathrm{d}}$ & $24.2^{\mathrm{b}}$ & 3.1 & 7.8 & $9.5^{\mathrm{ab}}$ & $78.3^{\mathrm{g}}$ & $19.8^{\mathrm{h}}$ & $36.9^{\mathrm{a}}$ & $935.4^{\mathrm{d}}$ & $5.91^{\mathrm{b}}$ & 4.81 \\
\hline & & 10 & $5.06^{\mathrm{a}}$ & $27.5^{\mathrm{a}}$ & 2.4 & 10.3 & $8.2^{\mathrm{c}}$ & $79.9^{\mathrm{d}}$ & $17.9^{\mathrm{m}}$ & $38.2^{\mathrm{a}}$ & $955.7^{\mathrm{cd}}$ & $6.57^{\mathrm{a}}$ & 5.14 \\
\hline SEM & & & 0.05 & 0.41 & 0.26 & 1.57 & 0.23 & 0.01 & 0.01 & 0.6 & 6.99 & 0.06 & 0.32 \\
\hline \multirow[t]{4}{*}{$P$-value ${ }^{1,2}$} & & $\mathrm{H}$ & $<0.0001$ & $<0.0001$ & $<0.0001$ & 0.0015 & $<0.0001$ & $<0.0001$ & $<0.0001$ & $<0.0001$ & $<0.0001$ & 0.0129 & 0.9221 \\
\hline & & $\mathrm{L}$ & $<0.0001$ & $<0.0001$ & $<0.0001$ & 0.0002 & $<0.0001$ & $<0.0001$ & $<0.0001$ & $<0.0001$ & 0.8832 & $<0.0001$ & 0.0335 \\
\hline & & $\mathrm{U}$ & $<0.0001$ & $<0.0001$ & 0.0029 & 0.0772 & $<0.0001$ & $<0.0001$ & $<0.0001$ & $<0.0001$ & $<0.0001$ & 0.0110 & 0.0558 \\
\hline & & Interaction & $\mathrm{H} \times \mathrm{L} \times \mathrm{U}^{* *}$ & $\mathrm{H} \times \mathrm{L} \times \mathrm{U}^{* *}$ & NS & NS & $\mathrm{H} \times \mathrm{L} \times \mathrm{U}^{* *}$ & $\mathrm{H} x \mathrm{~L} \times \mathrm{U}^{* *}$ & $\mathrm{H} \times \mathrm{L} \times \mathrm{U}^{* *}$ & $\mathrm{H} \times \mathrm{L} \times \mathrm{U}^{* *}$ & $\mathrm{Hx} \mathrm{U}^{*}$ & $\mathrm{H} \times \mathrm{L} \times \mathrm{U}^{* *}$ & NS \\
\hline \multirow[t]{2}{*}{ Main contrast ${ }^{3}$} & & $\mathrm{H}$ & $\mathrm{L}^{* *}$ & $\mathrm{Q}^{*}$ & $\mathrm{~L}^{* *}$ & $\mathrm{~L}^{*}$ & $\mathrm{Q}^{*}$ & $\mathrm{Q}^{* *}$ & $\mathrm{Q}^{* *}$ & $\mathrm{~L}^{* *}$ & $\mathrm{Q}^{*}$ & $\mathrm{~L}^{*}$ & NS \\
\hline & & $\mathrm{U}$ & $\mathrm{Q}^{* *}$ & $\mathrm{Q}^{* *}$ & $\mathrm{Q}^{*}$ & NS & $\mathrm{Q}^{* *}$ & $\mathrm{Q}^{* *}$ & $\mathrm{Q}^{* *}$ & $\mathrm{Q}^{* *}$ & $\mathrm{~L}^{* *}$ & $\mathrm{~L}^{*}$ & NS \\
\hline
\end{tabular}

${ }^{\mathrm{a}-\mathrm{p}}$ Means in the same column with different superscripts differed $(\mathrm{P}<0.05) ;{ }^{1} \mathrm{H}=$ hydration; $\mathrm{L}=$ liquid used at hydration; $\mathrm{U}=$ urea; ${ }^{2} \mathrm{NS}=$ no significant; ${ }^{*} \mathrm{P}<0.05 ; * * \mathrm{P}<0.01$.

${ }^{3} \mathrm{~L}=$ linear effect; $\mathrm{Q}=$ quadratic effect; ${ }^{4} \mathrm{mg} \mathrm{g}^{-1}$ of DM; L:A = lactic: acetic acid ratio; DM = dry matter; LAB = lactic acid bacteria 
The bakery by-product silages exhibited small concentrations of oxalic and phytic acid. The highest concentration of oxalic acid was observed in the silage hydrated with acid whey at $250 \mathrm{~mL} \mathrm{~kg}^{-1}$ without urea; whereas bakery by-product silage hydrated with acid whey at $300 \mathrm{~mL} \mathrm{~kg}^{-1}$ and treated with $5 \mathrm{~g} \mathrm{~kg}^{-1}$ of urea had highest concentration of phytic acid $(\mathrm{P}<0.01)$. According the hydration level increased, the total production of acid also increased $(\mathrm{P}<0.01)$. The highest values were obtained from hydration with acid whey at $350 \mathrm{~mL} \mathrm{~kg}^{-1}$ (regardless of urea rate), and water in the same amount treated with $5 \mathrm{~g} \mathrm{~kg}^{-1}$ of urea.

Overall, higher hydration levels decreased $(\mathrm{P}<0.05) 1.3 \%$ and $4.8 \%$ in DM recovery of bakery by-product silages (972.2, 959.6, and $925.0 \mathrm{~g} \mathrm{~kg}^{-1}$ of DM at 250, 300 , and $350 \mathrm{~mL} \mathrm{~kg}^{-1}$, respectively). The application of 5 and $10 \mathrm{~g} \mathrm{~kg}^{-1}$ of urea increased the DM recovery by $1.5 \%$ and $2.3 \%$, respectively, compared to untreated silages (940.5 $\mathrm{g} \mathrm{kg}^{-1}$ of DM). Evaluating the interaction between hydration level and urea rate, higher DM recovery was observed with hydration using water and acid whey at $250 \mathrm{~mL} \mathrm{~kg}^{-1}$ with 5 and $10 \mathrm{~g}$ $\mathrm{kg}^{-1}$ of urea.

The highest LAB population $(\mathrm{P}<0.01)$ was obtained in the bakery by-product silage hydrated with acid whey at $350 \mathrm{~mL}$ $\mathrm{kg}^{-1}$ and treated with $10 \mathrm{~g} \mathrm{~kg}^{-1}$ of urea, whereas the lower LAB populations were consequence of the hydration using water at 250 and $350 \mathrm{~mL} \mathrm{~kg}^{-1}$ and treated with 5 $\mathrm{g} \mathrm{kg}^{-1}$ of urea. Only the liquid used at hydration changed the fungi population $(\mathrm{P}<0.05)$, wherein the overall means were 5.35 and $5.01 \mathrm{cfu} \mathrm{g}^{-1}$ of fresh silage for water and acid whey, respectively. Moreover, acid whey reduced the fungi population by $30.3 \%$ after ensiling, whereas the reduction noted for water was only $10.7 \%$. Enterobacteria were evaluated but did not exhibit growth.
Despite the regression equations constructed from the hydration levels and urea rates used in the study, the higher $\mathrm{DM}$ and $\mathrm{OM}$ content were obtained by combining hydration at $250 \mathrm{~mL} \mathrm{~kg}{ }^{-1}$, regardless the liquid used, without the application of urea (Table 6). Otherwise, the higher concentration of lactic, acetic, and total acids were obtained by combining hydration at $350 \mathrm{~mL} \mathrm{~kg}$, regardless the liquid used, without or with $10 \mathrm{~g} \mathrm{~kg}^{-1}$ of urea. According to the regression equation the higher $\mathrm{DM}$ recovery $\left(817 \mathrm{~g} \mathrm{~kg}^{-1}\right.$ of $\left.\mathrm{DM} ; \mathrm{r}^{2}=0.86\right)$ was obtained by combining hydration at $250 \mathrm{~mL} \mathrm{~kg}^{-1}$, regardless the liquid used, with $10 \mathrm{~g} \mathrm{~kg}^{-1}$ of urea. However, the DM recovery obtained from the regression equation is considerable lower than those observed in the field (i.e., $>980 \mathrm{~g} \mathrm{~kg}^{-1}$ of $\mathrm{DM})$ for bakery by-product silage hydrated with water and whey at $250 \mathrm{~mL}$ $\mathrm{kg}^{-1}$ combined with $10 \mathrm{~g} \mathrm{~kg}^{-1}$ of urea.

\section{DISCUSSION}

As expected, the DM content decreased due to increases in hydration. Moreover, bakery by-product silage hydrated at 250 $\mathrm{mL} \mathrm{kg}{ }^{-1}$ and untreated with urea had higher DM content compared those hydrated with water at the same moisture content and urea rate. Acid whey had 51.4 $\mathrm{g} \mathrm{DM} \mathrm{kg}^{-1}$ as fed, which may explain the higher value for DM found in the silages due to use of this by-product. Overall, the silages hydrated with acid whey had a high production of short-chain fatty acids (SCFA), which contribute to increase the DM content (considering the correction when the silage was dried in the oven) and could also explain our results. Our data agree with those reported for HMC silages rehydrated with acid whey compared to water (REZENDE et al., 2014). 
Rev. Bras. Saúde Prod. Anim., Salvador, v.17, n.4, p.626-641 out./dez., 2016 http://www.rbspa.ufba.br ISSN 15199940

Table 6. Regression equations for chemical composition and fermentation profile $\left(\mathrm{g} \mathrm{kg}^{-}\right.$ ${ }^{1}$ of DM) of bakery by-product silages hydrated with water or acid whey and treated or not with urea $(\mathrm{n}=3)$

\begin{tabular}{|c|c|c|c|c|c|c|}
\hline \multirow{2}{*}{ Item } & \multirow{2}{*}{ Liquid } & \multirow{2}{*}{ Equation } & \multirow{2}{*}{$r^{2}$} & \multicolumn{2}{|c|}{ Optimal level } & \multirow{2}{*}{ Value } \\
\hline & & & & Hydration, $\mathrm{mL} \mathrm{kg}^{-1}$ & Urea, $\mathrm{g} \mathrm{kg}^{-1}$ & \\
\hline \multicolumn{7}{|c|}{ Interaction among hydration, liquid, and urea } \\
\hline \multicolumn{7}{|c|}{$\mathrm{DM}$} \\
\hline & Water & $\mathrm{Y}=1051-12.1 * \mathrm{H}^{1}+4.08 * \mathrm{U}^{1}$ & 0.89 & 250 & 0 & 748.5 \\
\hline & Whey & $\mathrm{Y}=1031-10.8 * \mathrm{H}-10.8 * \mathrm{U}$ & 0.85 & 250 & 0 & 761.0 \\
\hline \multicolumn{7}{|l|}{ OM } \\
\hline & Water & $\mathrm{Y}=991-0.29 * \mathrm{H}-7.79 * \mathrm{U}$ & 0.90 & 250 & 0 & 983.8 \\
\hline & Whey & $\mathrm{Y}=990-0.35 * \mathrm{H}-7.42 * \mathrm{U}$ & 0.93 & 250 & 0 & 981.3 \\
\hline \multicolumn{7}{|l|}{ Ash } \\
\hline & Water & $\mathrm{Y}=9.48+0.29 * \mathrm{H}+7.79 * \mathrm{U}$ & 0.90 & 250 & 0 & 16.7 \\
\hline & Whey & $\mathrm{Y}=9.99+0.35 * \mathrm{H}+7.42 * \mathrm{U}$ & 0.93 & 250 & 0 & 18.7 \\
\hline \multicolumn{7}{|c|}{ 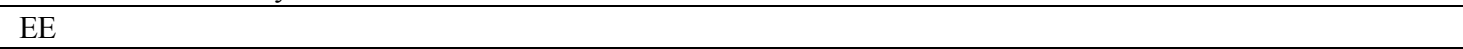 } \\
\hline & Water & $\mathrm{Y}=13.7+2.39 * \mathrm{H}+2.52 * \mathrm{U}$ & 0.81 & 350 & 10 & 99.9 \\
\hline & Whey & $\mathrm{Y}=8.24+2.88 * \mathrm{H}+1.48 * \mathrm{U}$ & 0.93 & 350 & 10 & 110.5 \\
\hline \multicolumn{7}{|c|}{ 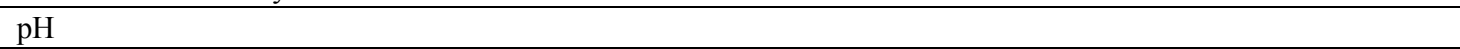 } \\
\hline & Water & $\mathrm{Y}=6.14-0.065 * \mathrm{H}+0.384 * \mathrm{U}$ & 0.79 & 350 & 0 & 3.9 \\
\hline \multicolumn{7}{|c|}{ Lactic acid } \\
\hline & Water & $\mathrm{Y}=-16.1+1.14 * \mathrm{H}+0.75 * \mathrm{U}$ & 0.87 & 350 & 10 & 24.6 \\
\hline & Whey & $\mathrm{Y}=-12.8+1.04 * \mathrm{H}+2.54 * \mathrm{U}$ & 0.95 & 350 & 10 & 26.1 \\
\hline \multicolumn{7}{|c|}{ Propionic acid } \\
\hline & Water & $\mathrm{Y}=-1.26+0.27 * \mathrm{H}-2.83 * \mathrm{U}$ & 0.67 & 250 & 10 & 2.7 \\
\hline & Whey & $\mathrm{Y}=-0.67+0.30 * \mathrm{H}-0.78 * \mathrm{U}$ & 0.68 & 250 & 10 & 6.1 \\
\hline \multicolumn{7}{|c|}{ Oxalic acid $^{2}$} \\
\hline & Whey & $\mathrm{Y}=864-2.98 * \mathrm{H}+17.0 * \mathrm{U}$ & 0.24 & 350 & 0 & 759.7 \\
\hline \multicolumn{7}{|c|}{ Total acids } \\
\hline & Water & $\mathrm{Y}=-176+14.8 * \mathrm{H}-19.2 * \mathrm{U}$ & 0.84 & 350 & 0 & 342.0 \\
\hline & Whey & $\mathrm{Y}=-135+14.4 * \mathrm{H}+9.86 * \mathrm{U}$ & 0.95 & 350 & 10 & 378.9 \\
\hline \multicolumn{7}{|c|}{ Interaction between hydration and liquid } \\
\hline \multicolumn{7}{|l|}{$\mathrm{CP}$} \\
\hline & Water & $\mathrm{Y}=58.0+1.98 * \mathrm{H}$ & 0.26 & 350 & - & 127.3 \\
\hline & Whey & $\mathrm{Y}=58.6+2.12 * \mathrm{H}$ & 0.32 & 350 & - & 132.8 \\
\hline \multicolumn{7}{|c|}{ Interaction between hydration and urea } \\
\hline \multicolumn{7}{|c|}{ DM recovery } \\
\hline & - & $\mathrm{Y}=1160-14.2 * \mathrm{H}+11.9 * \mathrm{U}$ & 0.86 & 250 & 10 & 816.9 \\
\hline \multicolumn{7}{|c|}{ No interaction (main effect of hydration) } \\
\hline \multicolumn{7}{|c|}{ Acetic acid } \\
\hline & - & $\mathrm{Y}=0.29+0.06 * \mathrm{H}$ & 0.16 & 350 & - & 2.4 \\
\hline \multicolumn{7}{|c|}{ Lactic:acetic acid ratio } \\
\hline & & $\mathrm{Y}=1.39+0.248 * \mathrm{H}$ & 0.14 & 250 & - & 7.6 \\
\hline
\end{tabular}

${ }^{1} \mathrm{H}=$ hydration; $\mathrm{U}=$ urea; $^{2} \mathrm{mg} \mathrm{g}{ }^{-1}$ of DM.

$\mathrm{DM}=$ dry matter $\left(\mathrm{g} \mathrm{DM} \mathrm{kg}^{-1}\right.$ as fed $) ; \mathrm{OM}=$ organic matter; $\mathrm{EE}=$ ether extract; $\mathrm{CP}=$ crude protein.

Relative to the fermentative process, bakery by-product silages hydrated at 350 $\mathrm{mL} \mathrm{kg}{ }^{-1}$ using water (plus $5 \mathrm{~g} \mathrm{~kg}^{-1}$ of urea) and acid whey (plus $10 \mathrm{~g} \mathrm{~kg}^{-1}$ of urea) exhibited higher production of lactic acid. However, in general acid whey increased the production of lactic acid.
Bakery by-product contains relatively small amounts of fermentable sugars (MORAES et al., 2010; ELLEUCH et al., 2011), which are required in the ensiling process for the production of acids (mainly lactic acid) by LAB. However, sugars are not the only compounds 
necessary for the LAB growth, which requires various amino acids and vitamins (PAHLOW et al., 2003). Therefore, these nutrients can be obtained from acid whey because this by-product is a rich source of soluble sugars (specifically lactose), proteins, minerals, and vitamins, besides a variable amount of lactic acid (VALDUGA et al., 2006) and LAB (SANTOS et al., 2006). In other words, acid whey is an additional source of substrate for LAB into the silo (SCHINGOETHE, 1976), as observed in the present study through increases in the ash, CP (mainly when associated to urea), and EE contents. These results explain why the bakery by-product silages hydrated with acid whey exhibited higher lactic acid concentrations in general.

Likewise, the explanation above helps us to understand the higher production of acetic acid when the silages were hydrated using acid whey. In general propionic acid was also higher in the silages hydrated with acid whey. Whey is a good source of fermentable carbohydrates (lactose), its addition at ensiling usually resulted in a more-rapid fermentation, more-complete fermentation and better silage quality (SCHINGOETHE, 1976), as indicated by the higher lactic acid and SCFA concentrations found in our study. Conversely, none of the silages exhibited the production of butyric acid, indicating that bakery by-product silages had a suitable fermentation process because butyric acid usually indicates clostridial fermentation (PAHLOW et al., 2003).

The silages exhibited small concentrations of oxalic and phytic acids, which showed a large variation between treatments. As known, oxalic and phytic acids are anti-nutritive compounds that can form complexes with minerals (mainly $\mathrm{Ca}$ ) and reduce their availability, as well as their absorption in the gastrointestinal tract (SOETAN \&
OYEWOLE, 2009). Although we did not evaluate the presence of these compounds on bakery by-product prior to ensiling, the concentration of oxalic and phytic acids should most likely be higher than that found in the silages because the ensiling process (fermentation) negatively affects these acids, as reported in tropical forage legumes (MARTENS et al., 2014). Although there are not studies about bakery by-product silages, the use of bakery by-products had been used as additive to improve the fermentation of cattle manure silages (BÓRQUEZ et al., 2009).

In contrast to the obvious benefits of acid whey hydration, the application of urea did not increase the production of organic acids; otherwise, the acetic and propionic acids decreased when a high urea rate was used at ensiling (except for the silages hydrated with acid whey at $250 \mathrm{~mL} \mathrm{~kg}^{-1}$ ). In theory, the goal of using urea is to reduce the occurrence of spoilage microorganisms to benefit the action of LAB into the silos, which could result in higher production of lactic acid and SCFA. In this sense, considering trends $(\mathrm{P}<0.10)$ and the statistical value observed for urea $(\mathrm{P}=0.0558)$, the fungi population of silages decreased according urea was applied (regardless of urea rate). However, our result agrees with other studies because data in the literature also do not exhibit changes in these organic acids with the application of urea (SCHMIDT et al., 2007). Therefore, these results most likely indicate that the majority of LAB population in our study should be homofermentative species, which basically produce only lactic acid (except under adverse conditions) in detrimental SCFA (MUCK, 2010; 2013). Additionally, the silages hydrated with water at $250 \mathrm{~mL} \mathrm{~kg}^{-1}$ and acid whey at $350 \mathrm{~mL} \mathrm{~kg}^{-1}$ had higher $\mathrm{pH}$ values when $10 \mathrm{~g} \mathrm{~kg}^{-1}$ of urea was applied. Urea is converted into ammonia and reacts with 
water forming ammonia hydroxide and resulting in $\mathrm{pH}$ increases, and reduces the activity of undesirable microorganisms (PEDROSO et al., 2008).

Overall, silages with high moisture resulted in higher concentration of lactic acid and SCFA, which has a $\mathrm{p} K_{a}$ approximately 3.8 and 4.7, respectively. Consequently, these silages had a lower $\mathrm{pH}$ than the silages hydrated at 250 and $300 \mathrm{~mL} \mathrm{~kg}^{-1}$ (except the silage hydrated with acid whey at $350 \mathrm{~mL} \mathrm{~kg}^{-1}$ and treated with $10 \mathrm{~g} \mathrm{~kg}^{-1}$ of urea). As previously described, acid whey is an additional source of nutrients for LAB; therefore, a high production of acids is expected when this by-product is added in greater amounts (hydration). Similarly, the growth of LAB, as well as for yeast and molds, is most likely more difficult if the moisture content is low due to lower water activity (PAHLOW et al., 2003). If we consider only hydration level in this study, the overall means for LAB were $5.79,5.87$, and 5.88 at 250,300 , and 350 $\mathrm{mL} \quad \mathrm{kg}^{-1} \quad$ (significantly different; $\mathrm{P}<0.05$ ), respectively. Therefore, homofermentative LAB most likely finds a better environment to act when the moisture content of silages is high, resulting in higher production of acids and the consequent $\mathrm{pH}$ reduction. Normally, the same result is observed for whole-corn silages, which exhibit a high production of total acids when the plant used at ensiling has high moisture content (WARD, 2000).

However, the higher DM recovery was obtained in the silages hydrated at 250 $\mathrm{mL} \mathrm{kg}^{-1}$ using water and acid whey in the presence of urea (5 and $10 \mathrm{~g} \mathrm{~kg}^{-1}$ ). As discussed above, urea has antifungal properties and because this is used as an additive for ensiling to control spoilage microorganisms (PEDROSO et al., 2008; 2011). As previously described, if trends is considered the urea rates of 5 and $10 \mathrm{~g}$ $\mathrm{kg}^{-1}$ reduced the fungi population of silages. Additionally, these silages had lower moisture content, which is also a challenge to action of spoilage microorganisms (REZENDE et al., 2014) most likely due to the lower water activity. Therefore, the lower moisture content and urea rates help us to understand the higher DM recovery found in the silages when these factors were combined.

Acid whey is an additional source of LAB (SANTOS et al., 2006), as demonstrated at ensiling when the application of this by-product increased the LAB population in the bakery byproduct. In theory, these bacteria could change the fermentative process avoiding higher losses. As observed, this theory was right because the production of total acids increased. However, although the production of lactic acid increased, the same was observed for acetic and propionic acids. Likewise, when the water and acid whey were added, the production of these acids also increased. The homolactic pathway (strictly produces lactic acid) is the most efficient for DM recovery into the silos allowing $100 \%$ of recovery in theory; but the heterolactic pathway (includes products in addition to lactic acid) usually reflects higher losses during fermentation because the recovery is $95 \%$ in theory but can be changed depending on the substrate that is used by LAB (MUCK, 2010; 2013), thereby helping us to understand the results reported in this study.

About the chemical composition, the acid whey used in this study had considerable amounts of ash, CP and EE, explaining why the contents of these variables increased in bakery by-products silages. Indeed, acid whey is a direct source of substrate to animal feeding (SCHINGOETHE, 1976), and its contribution to increase the $\mathrm{CP}$ content was previously reported in HMC silage (REZENDE et al., 2014). As expected, 
the $\mathrm{CP}$ content also increased in bakery by-product silage treated with urea. Urea is a non-protein-nitrogen additive that has been added at ensiling to increase the $\mathrm{CP}$ content of silage, and also to control spoilage microorganisms and to improve aerobic stability. Moreover, the increased $\mathrm{CP}$ content might enhance $\mathrm{CP}$ intake and feed efficiency in animals fed low-protein diet.

It is important to state once more that the discarding of bakery by-products in landfills (such occurred some years ago in Brazil) may cause many problems associated with environmental pollution. Moreover, bakery by-product has been used for swine (CORASSA et al., 2013; 2014), Holstein steers (PASSINI et al., 2001), and lambs (VIEIRA et al., 2008), but not always the animal performance was desirable, likely due to high production of mycotoxins by fungi in that by-product. Therefore, although the application of acid whey at ensiling also increased the fungi population in general, after the silos were opened the bakery byproducts silages hydrated with this byproduct exhibited lower fungi counts. Moreover, all bakery by-products silages (overall mean of $5.18 \mathrm{cfu} \mathrm{g}^{-1}$ ) had lower fungi population compared with the whole bakery by-product ( $6.15 \mathrm{cfu} \mathrm{g}^{-1}$ ) prior to ensiling. Thus, ensiling bakery by-product likely reduces the risks associated with animal diseases caused by micotoxins. Bakery products have a considerable population of molds and yeasts, mainly Penicillium and Aspergillus spp., which are able to growth especially in warmer climates and produce micotoxins (SUHR \& NIELSEN, 2004). Fungi spoilage can be a serious problem for bakery products if none additive is used in the conservation process of this food (SUHR \& NIELSEN, 2004). Acetic and propionic acids have antifungal properties under low $\mathrm{pH}$ that reduce the population of undesirable microorganisms during fermentation of silage (MOON, 1983). In other words, the ensiling of bakery by-product together acid whey is a good strategy to reduce the environment pollution as related to both by-products and may be an alternative to animal feeding on farms when conventional feedstuffs are scarce. Thus, future experiments evaluating the performance of animals fed bakery byproducts silages or in vitro studies are necessary to determine the contribution of these by-products to animal nutrition.

Conversely, despite the clear benefits of acid whey hydration on the chemical composition and fermentation of bakery by-product silage, its recommendation must consider the logistical system and location of a farm or property. Acid whey is relatively a low-cost additive, but its utilization may be restricted to the places near the dairy industries (i.e., $<10 \mathrm{~km}$ ), since costs about transportation can preclude its utilization, mainly for hydration of great amounts of feed. For instance, in the present study the acid whey hydration of bakery by-product at $250 \mathrm{~mL} \mathrm{~kg}{ }^{-1}$ was found to increase DM recovery. Thus, considering that optimal level of hydration are necessary 2,500,000 L of acid whey to ensile 10,000 tonnes of bakery by-product, which is likely impracticable due to the high costs about transportation. A simulation of costs about the use of acid whey as a feedstuff in the diet for swine showed its infeasibility due to the elevated costs associated with transportation (BERTOL et al., 1993).

In conclusion, the association between bakery by-product and acid whey shows a great potential for use in the ensiling process, improving the fermentative process of bakery by-product silages regardless of hydration level. However, hydration of bakery by-product with acid whey at $250 \mathrm{~mL} \mathrm{~kg}^{-1}$ is recommended because reduces fermentative losses of 
Rev. Bras. Saúde Prod. Anim., Salvador, v.17, n.4, p.626-641 out./dez., 2016 http://www.rbspa.ufba.br ISSN 15199940

silages. Additionally, the results of this study represent a practical strategy to avoid discarding both by-products in the environment. Although urea did not exhibit great benefits on the characteristics of bakery by-product silages their utilization cannot be disregarded because allowed higher DM recovery in those silages.

\section{REFERENCES}

ABIMAPI. Associação Brasileira das Indústrias de Biscoitos. Massas Alimentícias e Pães \& Bolos Industrializados, 2015. Anuário ABIMAPI. Available in: $<$ http://abima.com.br/cloud/ABIMAPI_A NUARIO_2015.pdf $>$.

ASSOCIATION OF OFFICIAL ANALYTICAL CHEMISTRY - AOAC. Official Methods of Analysis. $16^{\text {th }}$ ed. Washington, DC, USA, 1996.

BERTOL, T.M.; GOMES, J.D.F.; SILVA, E.D. Soro de leite integral na alimentação de suínos em crescimento e terminação. Revista da Sociedade Brasileira de Zootecnia, v.22, n.6, p.993-1002, 1993.

BÓRQUEZ, J.L.; GONZÁLEZMUÑOZ, S.S.; PINOS-RODRIGUEZ, J.M.; DOMÍNGUEZ, I.; BÁRCENA, J.R.; MENDOZA, G.D.; COBOS, M.A.; BUENO, G. Feeding value of ensiling fresh cattle manure with molasses or bakery by-products in lambs. Livestock Science, v.122, p.276-280, 2009.

CARVALHO, B.F.; ÁVILA, C.L.S.; PINTO, J.C.; PEREIRA, M.N.;

SCHWAN, R.F. Effects of propionic acid and Lactobacillus buchneri (UFLA SIL 72) addition on fermentative and microbiological characteristics of sugar cane silage treated with or without calcium oxide. Grass and Forage Science, v.67, p.462-471, 2012.

CORASSA, A.; BALLERINI, K.; KOMIYAMA, C.M.; PINA, D.S.; BALLERINI, N.; DAL MAGRO, T.R. Farelo de biscoito em rações para leitões na fase inicial. Comunicata Scientiae, v.4, n.3, p.231-237, 2013.

CORASSA, A.; PREZOTTO, R.T.; KOMIYAMA, C.M.; MOREIRA, P.S.A.; ARAÚJO, C.V. Farelo de biscoito na alimentação de porcas em lactação.

Pesquisa Agropecuária Tropical, v.44, p.42-49, 2014.

ELLEUCH, M.; BEDIGIAN, D.; ROISEUX, O.; BESBES, S.; BLECKER, C.; ATTIA, H. Dietary fibre and fibrerich by-products of food processing: Characterisation, technological functionality and commercial applications: A review. Food Chemistry, v.124, n.2, p.411-421, 2011.

FRANÇA, A.B.; MORENZ, M.J.F.; LOPES, F.C.F.; MADEIRO, A.S.; MORENZ, D.A.; FARIA, B.M.; CABRAL, L.S.; FONSECA, C.E.M. Bakery waste in sheep diets: intake, digestibility, nitrogen balance and ruminal parameters. Revista Brasileira de Zootecnia, v.41, n.1, p.147-153, 2012.

GARCIA, H.L.; ANDRADE, L.C.T.; ANDRADE JÚNIOR, L.C.; LUDGERO, G. Análise de perdas de produção de biscoitos na Mabel: controle estatístico de processo. In: ENCONTRO NACIONAL DE ENGENHARIA DE PRODUÇÃO, 31., 2011, Belo Horizonte, MG.

Proceedings... Belo Horizonte, MG, Brazil. 13p. 
Rev. Bras. Saúde Prod. Anim., Salvador, v.17, n.4, p.626-641 out./dez., 2016 http://www.rbspa.ufba.br ISSN 15199940

KUNG, L., J.R.; SCHIMIDT, R.J.; EBLING, T.E.; HU, W. The effect of Lactobacillus buchneri 40788 on the fermentation and aerobic stability of ground and whole high-moisture corn. Journal of Dairy Science, v.90, p.23092314, 2007.

KWAK, W.S.; KANG, J.S. Effect of feeding food waste-broiler litter and bakery by-product mixture to pigs.

Bioresource Technology, v.97, n.2, p.243-249, 2006.

MAKKAR, H.P.S.; ANKERS, P. A need for generating sound quantitative data at national levels for feed-efficient animal production. Animal Production Science, v.54, p.1569-1574, 2014.

MARTENS, S.D.; HOEDTKE, S.; AVILA, P.; HEINRITZ, S.N.; ZEYNER, A. Effect of ensiling treatment on secondary compounds and amino acid profile of tropical forage legumes, and implications for their pig feeding potential. Journal of Science Food and Agriculture, v.94, p.1107-1115, 2014.

MOON, N.J. Inhibition of the growth of acid tolerant yeasts by acetate, lactate and propionate and their synergistic mixtures. Journal of Applied Bacteriology, v.55, p.453-460, 1983.

MORAES, K.S.; ZAVAREZE, E.R.; MIRANDA, M.Z.; SALAS-MELLADO, M.M. Avaliação tecnológica de biscoitos tipo cookie com variações nos teores de lipídio e de açúcar. Ciência e Tecnologia de Alimentos, v.30, p.233-242, 2010.

MUCK, R.E. Silage microbiology and its control through additives. Revista Brasileira de Zootecnia, v.39, p.183191, 2010. (suplemento especial)
MUCK, R.E. Recent advances in silage microbiology. Agricultural and Food Science, v.22, p.3-15, 2013.

PAHLOW, G.; MUCK, R.E.; DRIEHUIS, F.; OUDE-ELFERINK, S.J.W.H.; SPOELSTRA, S.F.

Microbiology of Ensiling. In: Silage Science and Technology, BUXTON, D.R.; MUCK, R.E.; HARRISON, J.H. (Eds.). American Society of Agronomy, Madison, WI, 2003. p.31-93.

PASSINI, R.; SPERS, A.; LUCCI, C.S. Efeitos da substituição parcial do milho na dieta pelo resíduo de panificação sobre o desempenho de novilhos da raça Holandesa. Pesquisa Agropecuária Brasileira, v.36, n.4, p.689-694, 2001.

PEDROSO, A.F.; NUSSIO, L.G.; LOURES, D.R.S.; PAZIANI, S.F.; RIBEIRO, J.L.; MARI, L.J.; ZOPOLLATTO, M.; SCHMIDT, P.; MATTOS, W.R.S.; HORRI, J.

Fermentation, losses, and aerobic stability of sugarcane silages treated with chemical or bacterial additives. Scientia Agricola, v.65, n.6, p.589-594, 2008.

PEDROSO, A.F.; RODRIGUES, A.A.; BARIONI JÚNIOR, W.; SOUZA, G.B. Fermentation parameters, quality and losses in sugarcane silages treated with chemical additives and a bacterial inoculant. Revista Brasileira de Zootecnia, v.40, n.11, 2318-2322, 2011.

PIEPER, R.; HACKL, W.; KORN, U.; ZEYNER, A.; SOUFFRANT, W.B.; PIEPER, B. Effect of ensiling triticale, barley and wheat grains at different moisture content and addition of Lactobacillus plantarum (DSMZ 8866 and 8862) on fermentation characteristics and nutrient digestibility in pigs. Animal Feed Science and Technology, v.164, n.1, p.96-105, 2011. 
Rev. Bras. Saúde Prod. Anim., Salvador, v.17, n.4, p.626-641 out./dez., 2016 http://www.rbspa.ufba.br ISSN 15199940

PORTER, M.G.; MURRAY, R.S. The volatility of components of grass silage on oven drying and the inter-relationship between dry-matter content estimated by different analytical methods. Grass and Forage Science, v.56, p.405-411, 2001.

REZENDE, A.V.; RABELO, C.H.S.; VEIGA, R.M.; ANDRADE, L.P.; HÄRTER, C.J.; RABELO, F.H.S.; BASSO, F.C.; NOGUEIRA, D.A.; REIS, R.A. Rehydration of corn grain with acid whey improves the silage quality. Animal Feed Science and Technology, v.197, p.213-221, 2014.

RICHARDS, C.J.; HICKS, B. Processing of corn and sorghum for feedlot cattle.

Veterinary Clinics of North America: Food Animal Practice, v.23, n.2, p.207221, 2007.

SANTOS, E.M.; ZANINE, A.M.; FERREIRA, D.J.; OLIVEIRA, J.S.; PEREIRA, O.G.; ALMEIDA, J.C.C. Effect of cheese whey serum adittion on bromatologic, composition fermentation, losses and dry matter recovery in elephant grass silage. Ciência Animal Brasileira, v.7, p.235-239, 2006.

SCHINGOETHE, D.J. Whey utilization in animal feeding: a summary and evaluation. Journal of Dairy Science, v.59, p.556-570, 1976.

SCHMIDT, P.; MARI, L.J.; NUSSIO, L.G.; PEDROSO, A.F.; PAZIANI, S.F.; WECHSLER, F.S. Aditivos químicos e biológicos na ensilagem de cana-deaçúcar. 1. Composição química das silagens, ingestão, digestibilidade e comportamento ingestivo. Revista Brasileira de Zootecnia, v.36, n.5, p.1666-1675, 2007.
SOETAN, K.O.; OYEWOLE, O.E. The need for adequate processing to reduce the anti-nutritional factors in plants used as human foods and animal feeds: A review. African Journal of Food Science, v.3, n.9, p.223-232, 2009.

SUHR, K.I.; NIELSEN, P.V. Effect of weak acid preservatives on growth of bakery product spoilage fungi at different water activities and $\mathrm{pH}$ values.

International Journal of Food

Microbiology, v.95, p.67-78, 2004.

VALDUGA, E.; PAVIANI, L.C.; MAZUR, S.P.; FINZER, J.R.D.

Aplicação do soro de leite em pó na panificação. Alimentos \& Nutrição, v.17, n.4, p.393-400, 2009.

VIEIRA, P.F.; CALDARA, F.R.; ANDRADE, G.A.; REZENDE, A.V.; GIOSO, M.M.; LEIRA, M.H.; VILELA, H.H. Digestibilidade da matéria seca e proteína bruta do resíduo seco de padaria em ovinos. ARS Veterinaria, v.24, p.5358, 2008.

WARD, R. Fermentation Analysis: Use and Interpretation. In: Tri-State Dairy Nutrition Conference, Fort Wayne, Indiana, USA, 2000. p.117-135.

Data de recebimento: 09/03/2016

Data de aprovação: 20/10/2016 